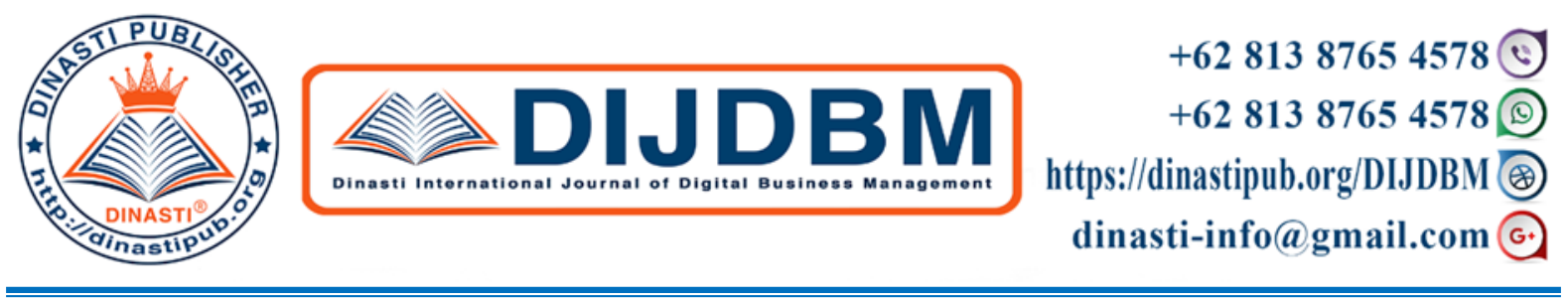

\title{
COMPARATIVE STUDY DECISION SUPPORT SYSTEM AHP AND SAW METHOD IN TENDER PROCESS TV TRANSMISSION STATIONS
}

\author{
Purwono Sutoyo $^{\text {1), Dewi Nusraningrum }}{ }^{2)}$ \\ ${ }^{1)}$ Mercu Buana University, Jakarta, Indonesia \\ ${ }^{2)}$ Mercu Buana University, Jakarta, Indonesia
}

\begin{tabular}{|c|c|}
\hline $\begin{array}{l}\text { ARTICLE INFORMATION } \\
\text { Received: } 27^{\text {th }} \text { July } 2020 \\
\text { Revised: } 15^{\text {th }} \text { August } 2020 \\
\text { Issued: } 23^{\text {th }} \text { August } 2020 \\
\text { Corresponding author: } \\
\text { Purwono Sutoyo } \\
\text { E-mail: } \\
\text { dewinusraningrum@gmail.com } \\
\text { DOI:10.31933/DIJDBM }\end{array}$ & $\begin{array}{l}\text { Abstract. This research compares two methods of } \\
\text { Decision Support System, namely: Analytical Hierarchy } \\
\text { Process (AHP) and Simple Additive Weighting (SAW), } \\
\text { by taking a case study regarding the tender process of } \\
\text { MNC television transmission stations for Denpasar } \\
\text { locations. Based on four main criteria, namely: price, } \\
\text { quality, service and reliability in determining the winner } \\
\text { of the tender followed by three alternative participants } \\
\text { (PT. Axx, PT. Nx and PT. Lxx). Sampling in this study } \\
\text { uses a purposive sampling or judgment sampling method } \\
\text { based on the consideration of the personnel (informants) } \\
\text { involved directly or indirectly in the tender process. The } \\
\text { final result of the calculation using the AHP method } \\
\text { shows that the alternative priorities ranked 1st to 3rd are } \\
\text { PT. Axx total value of 0.592, PT. Nx total value of } 0.274 \\
\text { and PT. Lxx total value of 0.134. While the calculation } \\
\text { using the SAW method obtained an alternative priority } \\
\text { ranking 1st to 3rd is PT. Axx total value of } 0.95325 \text {, PT. } \\
\text { Nx total value of 0.92185 and PT. Lxx total value is } \\
\text { 0.71585. Quality criteria are the main priority in the } \\
\text { selection of vendors, reliability, service and price criteria } \\
\text { are the next priorities. The final score results obtained } \\
\text { from various calculations are not the same, which } \\
\text { indicates that the maturity of the data that is processed to } \\
\text { become accurate information is different. The SAW } \\
\text { method is more widely used because the calculation } \\
\text { process is easier to understand, fast and simple than the } \\
\text { AHP method. Whereas AHP is superior in data accuracy, } \\
\text { because the value of criteria weights is not arbitrarily } \\
\text { determined, but is generated based on calculations. } \\
\text { Keywords: Tender, Comparison, Criteria, Alternatives, } \\
\text { AHP, SAW }\end{array}$ \\
\hline
\end{tabular}




\section{INTRODUCTION}

In an effort to increase TV advertising revenue by maintaining the quality and performance of broadcasts to become TV viewers of choice.

For this reason MNC Media conducted a tender process to determine the winner as a construction project contractor who implemented the $4 \mathrm{tv}$ group integrated transmission station in Denpasar.

Focusing on the problem that, the company has suffered fixed asset broadcast losses due to rental financing, especially GTV (see table 1) and iNews since 2006, there has been a decrease in orientation in preparing the decision making system, the problem of the procurement team due to the absence of reference decision support systems in the tender process.

Table 1. Value of GTV Denpasar rent 2006-2018 (in millions of rupiah)

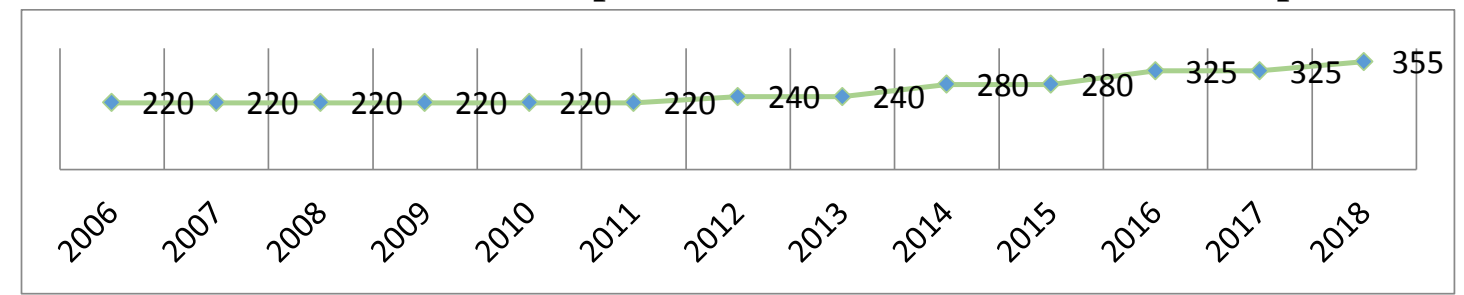

Source: Internal Finance GTV (2019)

The manual scoring method is still used (summing and weighting), with simple criteria and has a weakness that is a system that is too practical but the technical clarification process is sometimes long so that the potential is not objective. So this research is focused on how to make a decision-making system that can help the relevant part in prequalifying contractors, constructing models using the Analytical Hierarchy Process (AHP) method and the Simple Additive Weighting (SAW) method, and comparing them in the case of selecting winner tender television station transmission. Objective of this research is:

a. To make a decision making system with a better and more suitable method that will be used in the selection of tender winners in the Integration Transmission Division.

b. To compile the Decision Support System (DSS) program using the AHP method in assisting the relevant sections in the Integration Transmission Division so that they are not wrong in making decisions in determining the tender winners in accordance with predetermined criteria.

c. To compile the DSS program using the SAW method in helping the relevant sections in the Integration Transmission Division so that they are not wrong in making decisions in determining the tender winners in accordance with predetermined criteria.

d. To find out the comparison of DSS between AHP method and SAW method.

\section{LITERATURE REVIEW}

Supplier (Vendor). Intensively support the manufacturing process; their quality form of the quality of the final product that sells the business to their customers, supplier prices will affect the cost of manufacturing the product. Suppliers must be able to anticipate 
competitors trying to imitate, duplicate or defeat rivals on a variety of differentiation variables that produce competitive advantages (David, 2011).

Contractor. Defined as a person or entity who accepts work and carries out work according to costs that have been determined based on drawing plans and regulations and the conditions set (Ervianto, 2005). From the scale of its business the contractor can be classified into: small-scale contractor (local), medium-scale contractors, national scale contractor, international scale contractor. The purpose of this classification is so that existing business entities can participate in tenders and work on projects in accordance with their capacity while simultaneously maintaining business continuity for the middle to small groups. According to the Construction Services Development Institute ( $L P J K)$, business entities of the type of Construction Implementation Services can be divided into: Architecture, ElectricalMechanical, Integrated Work, Civil, Environmental Management.

Tender Process. The procurement of goods and services, especially in this research, goes through several stages starting from vendor selection, anwijzing process, acceptance of offers from vendors in accordance with the Term of Reference (TOR) and Scope of Work (SOW) instructions. Furthermore, the results of the technical team's assessment (clarification and evaluation) will be used as a guide by the purchasing team that leads to the negotiation stage until the determination of the tender winner by issuing a Purchase Order (PO).

The system used in evaluating the technical tender that has been running so far uses a manual appraisal system, namely the addition and weighting model. The evaluation carried out by the technical team is to check and ensure that each specification has been fulfilled by bidders based on the information submitted. Compliance with technical specifications using criteria: compliant or non-compliant. The weight calculation for each assessment is done manually, without using a DSS to carry out the calculation of points for technical evaluation. (Cheng \& $\mathrm{Li}, 2004)$ states that if there is no system or technique to accurately assess the most suitable tender, project performance can be affected. Therefore, transparent and flexible guidance tools to support tender assessment are needed to produce more effective evaluations (Mohemad et al., 2010; Chua et al., 2015).

Decision Support System (DSS). (Permana, 2015) is a system that can help someone in making decisions from various types of choices made accurately and in accordance with the desired goals. DSS (Turban and Aronson 2011: 75) is a system intended to support managerial decision-makers in semitructured and structured decision situations. The purpose of the DSS (Peter G. Keen and Scott Morton in Mc.Leod R, Jr., 1996) namely: help managers make decisions to solve semi-structured problems; supports manager's judgment rather than trying to replace it; improve the effectiveness of manager decision making rather than efficiency.

AHP (Analytical Hierarchy Process). It is a decision support model developed by Thomas L. Saaty, by breaking down complex multi-factor or multi-criteria problems into a hierarchy. Steps for decision making using the AHP method (Kadarsyah Suryadi and Ali Ramdhani, 2017) and (Sinaga, 2009):

a. Define the problem and determine the desired solution. 
b. Create a hierarchical structure that starts with general objectives, followed by criteria to sub-criteria (if possible needed), and alternative choices to be ranked.

c. Element Rating or Comparison

d. Matrix Preparation and Consistency Test

SAW (Simple Additive Weighting), often also known as the weighted sum method. The basic concept of the SAW method is to find a weighted sum of the performance ratings for each alternative on all attributes (Fishburn, Mac Crimmon, Agun Witjaksono, 2016). The steps for completing the SAW method are as follows:

a. Determine the criteria that will be used as a reference $(\mathrm{Ci})$

b. Determine the suitability rating of each alternative on each criterion.

c. Make a decision matrix based on criteria (Ci), then normalize based on an equation that is adjusted to the type of attribute (profit or cost attribute) to obtain an normalized matrix R.

$\mathrm{d}$. The final result is obtained from the ranking process that is the sum of the multiplication matrix normalized $\mathrm{R}$ with a weight vector so that the greatest value is chosen as the best alternative (Ai) as the solution.

\section{RESEARCH METHODS}

Research type and design. The design used is descriptive and comparative research. Descriptive research is chosen so that the findings can be more detailed because what is examined is not just the problem itself, but other variables related to the problem. Comparative research (Sudijono Anas, 2009: 273 and 287) is basically research that seeks to find similarities and differences about objects, people, work procedures, ideas, criticisms of people or groups, on ideas or work procedures.

Table 2. Operationalization and Measurement of Variables.

\begin{tabular}{|c|c|c|c|c|}
\hline No & Variable & Dimension & Concepts and Indicators & Scale \\
\hline \multirow[t]{2}{*}{1} & $\begin{array}{l}\text { Price/P } \\
\text { (independent } \\
\text { variable) }\end{array}$ & $\begin{array}{l}\text { - Competition } \\
\text { oriented pricing }\end{array}$ & $\begin{array}{l}\text { This is the amount of money charged for a product or service, or the } \\
\text { amount of value that consumers exchange for the benefits of owning or } \\
\text { using the product or service. (Kotler and Keller, 2010: } 314 \text { ). (Samsul } \\
\text { Ramli, 2013: 51), price is a relative value of a product and is not a } \\
\text { definite indicator of showing the amount of resources needed to produce } \\
\text { a product. }\end{array}$ & \\
\hline & & & $\begin{array}{l}\text { 1. Appropriate and reasonable price for the services provided } \\
\text { 2. Being able to give discounts }\end{array}$ & Ordinal \\
\hline \multirow[t]{2}{*}{2} & $\begin{array}{l}\text { Quality/Q } \\
\text { (independent } \\
\text { variable) }\end{array}$ & $\begin{array}{l}\text { - Performance, } \\
\text { - Conformance to } \\
\text { specification, } \\
\text { - Service ability, } \\
\text { - Features }\end{array}$ & $\begin{array}{l}\text { Based on the perspective of TQM (Total Quality Management), quality is } \\
\text { seen in a more comprehensive or holistic manner, where not only are the } \\
\text { results aspects emphasized, but also include processes, the environment, } \\
\text { and human resources. This perspective was formulated in detail (Goetsch } \\
\text { and Davis in Tjiptono and Chandra, 2011) who defined quality as } \\
\text { "dynamic conditions relating to products, services, human resources, } \\
\text { processes, and the environment that meet or exceed expectations. }\end{array}$ & \\
\hline & & & $\begin{array}{l}\text { 1. The services provided must conform to company specifications } \\
(K P I) \\
\text { 2. Able to anticipate work accidents }(K 3) \\
\text { 3. The ability to present information that is clear and easy to understand }\end{array}$ & Ordinal \\
\hline \multirow[t]{2}{*}{3} & $\begin{array}{l}\text { Service/S } \\
\text { (independent } \\
\text { variable) }\end{array}$ & $\begin{array}{l}\text { - Assurance, } \\
\text { - Emphaty }\end{array}$ & $\begin{array}{l}\text { (Sampara in Sinambela, 2011: 5), service is an activity or sequence of } \\
\text { activities that occur in direct interaction between someone with another } \\
\text { person or machine physically, and provides customer satisfaction. } \\
\text { According to the Big Indonesian Dictionary (KBBI), service is an effort } \\
\text { to help prepare or take care of what others need. }\end{array}$ & \\
\hline & & & $\begin{array}{l}\text { 1. Easy to communicate in terms of service from pre to post } \\
\text { procurement }\end{array}$ & Ordinal \\
\hline
\end{tabular}




\begin{tabular}{|c|c|c|c|}
\hline & & $\begin{array}{l}\text { 2. Quick in giving responses or responses } \\
\text { 3. Able to present information that is clear and easy to understand }\end{array}$ & \\
\hline \multirow[t]{2}{*}{4} & \multirow[t]{2}{*}{$\begin{array}{l}\text { Reliability/R } \\
\text { (independent } \\
\text { variable) }\end{array}$} & $\begin{array}{l}\text { Something that refers to the consistency of scores achieved by the same } \\
\text { person (party) when they are tested with the same test on different } \\
\text { occasions or with a set of different equivalent items or under different } \\
\text { test conditions (Anastasia and Susana, 2017) }\end{array}$ & \\
\hline & & $\begin{array}{l}\text { 1. Easy communication access in terms of after sales service ( } 24 \text { hours) } \\
\text { online help } \\
\text { 2. Ability in handling problems in the field }\end{array}$ & Ordinal \\
\hline \multirow[t]{2}{*}{5} & \multirow{2}{*}{$\begin{array}{l}\text { Decision on } \\
\text { the selection } \\
\text { of winners } \\
\text { (dependent } \\
\text { variable) }\end{array}$} & $\begin{array}{l}\text { A tender is a series of bidding activities aimed at selecting, obtaining, } \\
\text { determining and appointing which company is suitable and eligible for a } \\
\text { work package (Alfian Malik, 2010). }\end{array}$ & \\
\hline & & $\begin{array}{l}\text { 1. Effect of quality of work and results } \\
\text { 2. Price effect } \\
\text { 3. Influence of vendor facilities and services } \\
\text { 4. Effect of guarantee of work processes } \\
\text { 5. Influence of capabilities and solutions in the field }\end{array}$ & Ordinal \\
\hline
\end{tabular}

Type of this research uses a combination research approach (mixed method). Combined research (Sugiyono, 2017: 404) is a research method that combines quantitative and qualitative methods to be used together in a research activity, so that the data obtained are more comprehensive, valid, reliable, and objective. In this study, researchers developed concepts and collected facts but did not test hypotheses. (Sugiyono, 2009: 93) said that: "Research that is exploratory and often also in descriptive research does not need to formulate a hypothesis." Research to be conducted by researchers focuses on the research objectives that have been mentioned previously.

The population and sampling, in this study is all tenders within the scope of all subsidiary units under MNC Group in the form of construction projects, procurement of technical equipment, installation services and maintenance contracts. The sample in this study used a purposive sampling or judgment sampling method based on the consideration of the personnel (informants) who were directly or indirectly involved in the tender process for the construction of a transmission station in Denpasar, as many as 15 people.

Data sources and analysis methods. The data used are primary and secondary data (Sekaran, 2016), while data collection techniques use: field research including observation, interviews and questionnaires, library research and internet research. Data analysis method used in this study is the combination of manual calculations using Microsoft Excel and with the help of Expert Choice v11 software on both AHP (Analytic Hierarchy Process) and SAW (Simple Additive Weighting) methods.

\section{FINDINGS AND DISCUSSION}

Research result. The selection of respondents is based on criteria or expert opinion approaches. This approach assumes, people or various departments or areas of expertise, understand and master the problems and questions that will be asked or asked for opinions about it. Considering this research examines the issue of an effective tender process on an MNC Media transmission project, the respondents selected by the researchers deliberately reflect all the teams that run the tender process, representing the three main elements in MNC Media's internal team for this research, namely: top management (BOD) ), Finance (procurement, finance), technical (system engineer, operational user). 


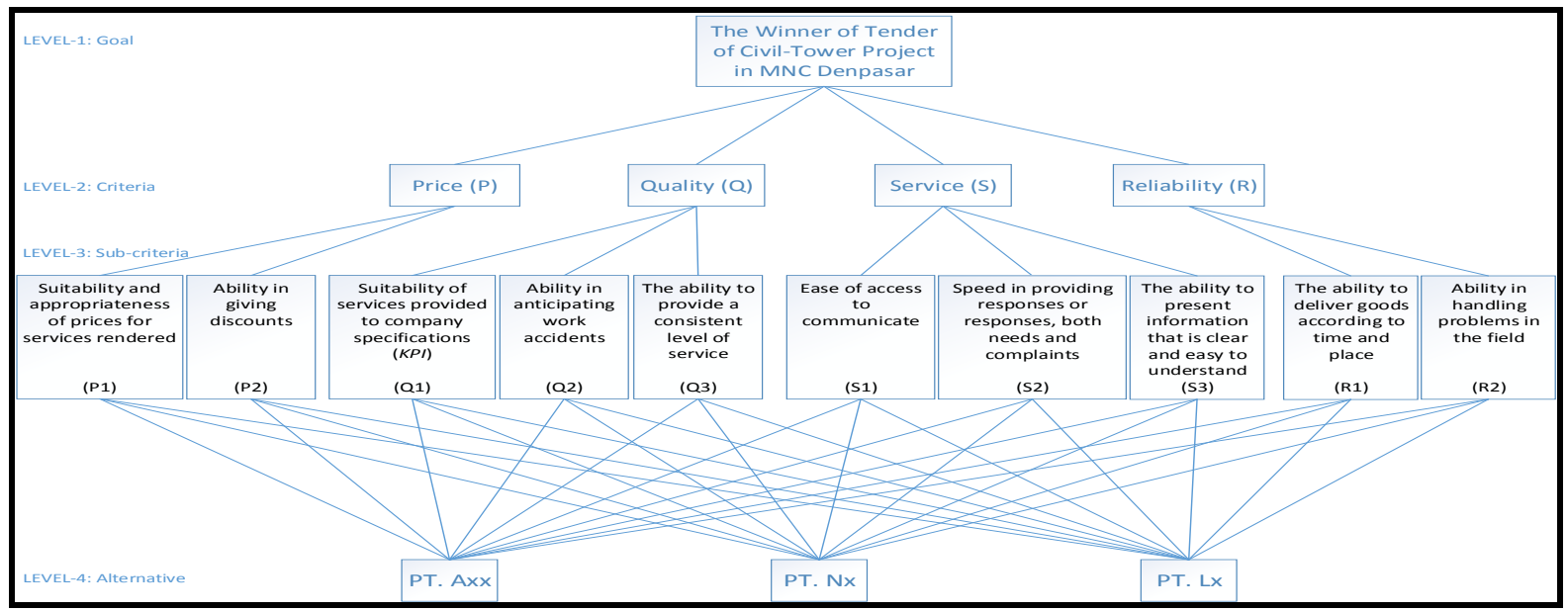

Source: Results of research data processing (2019)

Figure 1. Hierarchy as Results of Processing by AHP Method

Researchers divide into four levels (as in figure 1), namely: level-1 (goal) is the level that will be the final output to be achieved in this study. Level-2 (criteria), using 4 criteria in this study as stated (Liu and Hai, 2005) used in vendor selection, namely: Price, Quality, Service and Reliability. The four criteria are also included in the 21 criteria (Dickson in Pujawan and Mahendrawathi, 2010). The level-3 (sub-criteria) is obtained from the results of the interview. Level-4 (alternative) are a number of vendors who have offered.

\section{Weight Level Consistency Test and Priority Criteria.}

Because there is more than one expert respondent who gives weight between criteria, subcriteria and the assessment of several alternatives (vendors). To continue the AHP calculation, the geometric mean formula is used, namely:

$G M=\sqrt[n]{\left(x_{1}\right)\left(x_{2}\right) \ldots\left(x_{n}\right)}$

Where: $\quad G M=$ Geometric Mean

$$
\begin{array}{ll}
x_{1} & =1 \text { st expert } \\
x_{2} & =2 \text { nd expert } \\
x_{n} & =\mathrm{n} \text { th expert }
\end{array}
$$

then the geometric mean results for pairwise comparison between the criteria in table 3

\begin{tabular}{|c|c|c|c|c|}
\hline \multicolumn{5}{|c|}{ Compare the relative importance with respect to: Goal: The Winner of Tender of Civil-Tower Project in MNC Denpasar } \\
\hline & Price (P) & Quality (Q) & Service $(S)$ & Reliability (R) \\
\hline Price (P) & & 1,88675 & 1,05843 & 1,16407 \\
\hline Quality (Q) & & & 2,34012 & 2,2337 \\
\hline Service (S) & & & & 1,0601 \\
\hline Reliability $(\mathbb{R})$ & Incon: 0,00 & & & \\
\hline
\end{tabular}
below:

Table 3. Pairwise Comparisson Matrix between Criteria

Source: Results of research data processing (2019) 
Table 3, shows the results on the six cells that were weighted, it is found that:

- The weighted value of Quality (Q) $\mathbf{1 . 8 8 6 7 5}$ times slightly more important than Price (P).

- The weighted Service (S) $\mathbf{1 . 0 5 8 4 3}$ times slightly more important than Price $(\mathrm{P})$ or Price $(\mathrm{P})$ is almost as important as Service $(\mathrm{S})$.

- The weight value of Reliability (R) 1.16407 times slightly more important than Price (P).

- The weight of the Quality (Q) 2.34012 times more important than the Service (S)

- The weight value of Quality (Q) 2.23378 times more important than Reliability (R)

- The weight value of Reliability (R) 1.0601 times slightly more important than Service (S) or Service (S) is almost as important as Reliability (R)

Furthermore, it is calculated to get the priority order between the criteria, the results of which are shown in Figure 2 below.

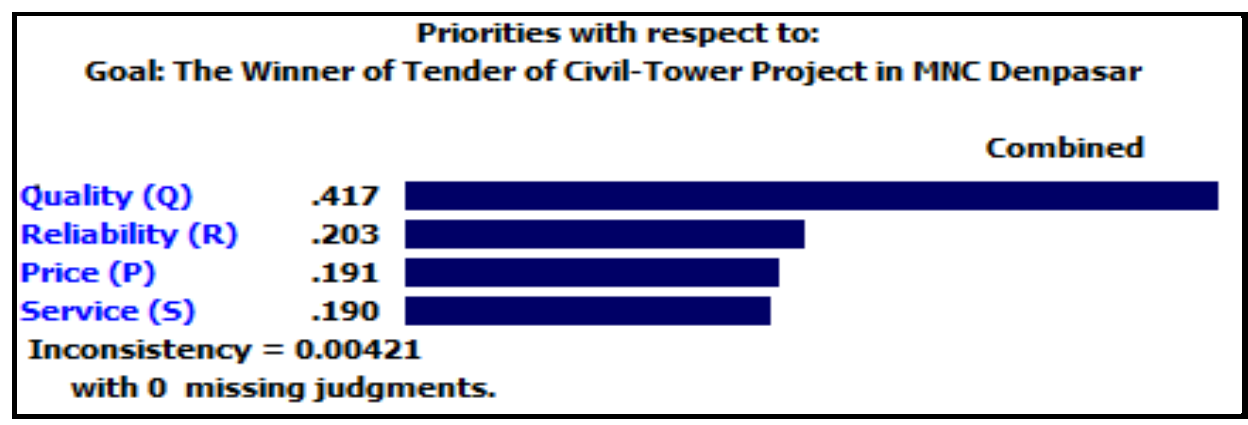

Source: Results of research data processing (2019)

Figure 2. Priority Weight Value Diagram between Criteria

Furthermore, it is calculated to get the priority order between the criteria, the results of which are shown in Figure 2. From Figure 2, we can know the order of priority criteria in determining the tender winner of the Denpasar transmission station project, the first priority is the quality criteria with a weight value of $\mathbf{0 . 4 1 7}$, then the reliability criteria with a weight value of $\mathbf{0 . 2 0 3}$, the third priority is the price criteria with the weight value is $\mathbf{0 . 1 9 1}$, the last criteria for service with a weight value of $\mathbf{0 . 1 9 0}$. Between the second to fourth priority has a value that is almost close to equal with a little difference. Researchers have ensured that at the consistency test stage on each respondent who assesses or assigns weights according to using a Consistency Ratio (CR) matrix <10\% (0.1) means that opinion inconsistencies are considered acceptable. After assessing the weights at the level of criteria up to the level of sub-criteria still with the Expert Choice program. Then enter the iteration stages for setting priorities on alternative options (vendors) until you get the results.

\section{Discussion of Results in AHP Method}

Result (figure 2) can be a reference that quality weight is the most important indicator for the MNC station project procurement team in the selection of work partners (vendors). There is a big difference between the criteria of quality $(Q)$ with the reliability $(\mathbf{R})$ of $\mathbf{0 . 2 1 4}$, so it can be said that quality has a very large weight. This is because MNC Media focuses on the field of television services that provide information, entertainment and knowledge that prioritizes 
quality in the presentation of services to customers so that partners (vendors) must be able to follow the flow and have quality standards that conform to the specifications set by the company. Then the final result of the alternative weight values up to the sub-criteria level can be seen as follows:

Price criteria that have the highest weighting sub-criteria achievement are:

P2 is $13.7 \%$. Obtained an alternative priority sequence, namely: PT. Axx (0.070); PT. Nx (0.044); PT Lxx (0.023). P1 is 5.4\%. Obtained an alternative priority sequence, namely: PT. Axx (0.031); PT. Nx (0.016); PT. Lxx (0.007).

In the Quality criteria, which has the highest weighting achievement sub-criteria, namely: Q1 reaches 20.7\%. Obtained an alternative priority sequence, namely: PT. Axx (0.124); PT. Nx (0.057); PT. Lxx (0.026). Q2 of 10.6\%. The priority order is: PT. Axx (0.061); PT. Nx (0.028); PT. Lxx (0.017). Q3 of 10.5\%. Obtained an alternative priority sequence, namely: PT. Axx (0.068); PT. Nx (0.024); PT Lxx (0.013).

Furthermore, the Service criteria, with the highest achievement of sub-criteria weights are: S2 of 9.0\%. Obtained an alternative priority sequence, namely: PT. Axx (0.054); PT. Nx (0.023); PT. Lxx (0.013). S3 of 5.1\%. The priority order is: PT. Axx (0.028); PT. Nx (0.017); PT Lxx (0.006). S1 by $4.9 \%$. Obtained an alternative priority sequence, namely: PT. Axx (0.029); PT. Nx (0.014); PT Lxx (0.006).

Last is the Reliability criteria, the highest weighting sub-criteria values are:

R2 of $13.1 \%$. Obtained an alternative priority sequence, namely: PT. Axx (0.045); PT. Nx (0.017); PT. Lxx (0.009). R1 (Ability to ship items according to time and place) of $7.1 \%$. The priority order is: PT. Axx (0.082); PT. Nx (0.034); PT Lxx (0.015).

Based on (10) ten sub-criteria used in this research, the percentage of alternative final values (vendors) is: PT. Axx (59.2\%); PT. Nx (27.4\%); PT Lxx (13.4\%).

This result clearly shows that the best vendor to be chosen by the company is PT. Axx because overall has the highest priority weight value compared to other alternatives calculated using the AHP method. The results of the paired matrix consistency test are included in the consistent category so that the results of the study can be stated in accordance (valid), shown in table 6 below.

Table 6. Consistency Test Results Data

\begin{tabular}{lcl}
\hline \multicolumn{1}{c}{ Paired Matrix } & CR & Remarks \\
\hline Between Criteria & 0.0042 & Consistent \\
Between Sub Criteria (Price/ P) & 0.0000 & Consistent \\
Between Sub Criteria (Quality/ Q) & 0.0003 & Consistent \\
Between Sub Criteria (Service/ S) & 0.0020 & Consistent \\
Between Sub Criteria (Reliability/ R) & 0.0000 & Consistent \\
Inter-Alternative (P1) & 0.0027 & Consistent \\
Inter-Alternative (P2) & 0.0136 & Consistent \\
Inter-Alternative (Q1) & 0.0165 & Consistent \\
Inter-Alternative (Q2) & 0.0134 & Consistent \\
Inter-Alternative (Q3) & 0.0142 & Consistent \\
Inter-Alternative (S1) & 0.0021 & Consistent \\
Inter-Alternative (S2) & 0.0000 & Consistent \\
Inter-Alternative (S3) & 0.0048 & Consistent
\end{tabular}




\begin{tabular}{ccc} 
Inter-Alternative (R1) & 0.0104 & $\begin{array}{c}\text { Consistent } \\
\text { Consistent }\end{array}$ \\
Inter-Alternative (R2) & 0.0028 & \\
\hline Source: Results of research data processing (2019) &
\end{tabular}

Processing Results by the SAW Method. The comparison in this study is to use the SAW method. The structural hierarchy is shown in Figure 3 below:

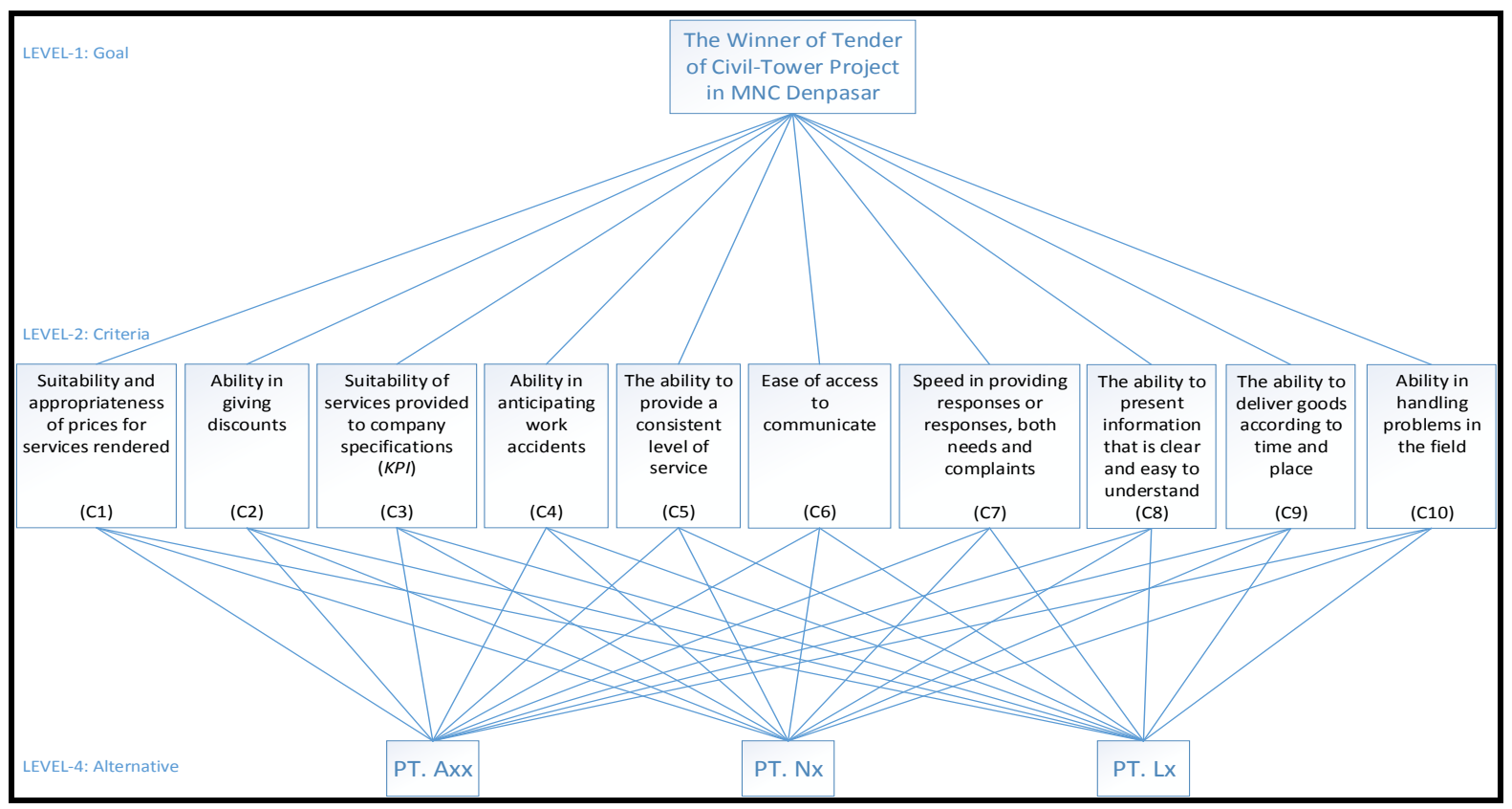

Source: Results of research data processing (2019)

Figure 3. Hierarchy as Results of Processing by SAW Method

The sequence of steps that need to be carried out in the SAW method:

a. Make Data on Likert Scale Results and Criteria Weight. This method requires criteria and weights to do the calculations so the results will get the best alternative (vendor). By finding the mode values in a single data set, so the mode values for each alternative with questions according to the criteria are shown in table 7 below:

Table 7. Value of Satisfaction Mode for Each Alternative

\begin{tabular}{llccc}
\hline No & \multicolumn{1}{c}{ Criteria } & $\begin{array}{c}\text { PT. } \\
\text { Axx }\end{array}$ & PT. Nx & PT. Lxx \\
\hline 1 & $\begin{array}{l}\text { Suitability and appropriateness of prices for services rendered } \\
\text { (P1) }\end{array}$ & 4 & 4 & 3 \\
2 & Ability in giving discounts (P2) & 4 & 3 & 3 \\
3 & The suitability of the services provided to company specifications \\
& (KPI) (Q1) & 4 & 4 & 3 \\
4 & Ability in anticipating work accidents (Q2) & 4 & 4 & 3 \\
5 & The ability to provide a consistent level of service (Q3) & 4 & 3 \\
6 & Ease of access to communicate (S1) & 4 & 4 \\
7 & Speed in providing responses or responses, both needs and & 4 & 4 \\
8 & complaints (S2) & & 2 \\
& The ability to present information that is clear and easy to & 4 & 4
\end{tabular}




\begin{tabular}{lllll} 
& understand (S3) & & 3 & 2 \\
9 & The ability to deliver goods according to time and place (R1) & 4 & 3 & 2 \\
\hline
\end{tabular}

Source: Results of research data processing (2019)

Next determine the weight value per criterion (Wij), the weight value of the existing criteria is determined by the decision maker, in this case from the average results of the respondents. The results of the mean geometric calculation of the AHP method weight criteria can be applied to this SAW method, in order to obtain an equivalent weight ratio of criteria (apple to apple) in both methods. In this study, the independent variables used are the same as assessing vendor performance sub criteria in the AHP method. So we can know the value of the weight and status criteria in the SAW method, shown in table 8 below.

Table 8. Weight Weights and Status of each Criteria

\begin{tabular}{cllc}
\hline Criteria & \multicolumn{1}{c}{ Information } & Status & $\begin{array}{c}\text { Weight }(\boldsymbol{W}) \\
(\mathbf{\%})\end{array}$ \\
\hline C1 & Suitability and appropriateness of prices for services rendered (P1) & Cost & 5.4 \\
C2 & Ability in giving discounts (P2) & Cost & 13.7 \\
C3 & The suitability of the services provided to company specifications (KPI) (Q1) & Benefit & 20.7 \\
C4 & Ability in anticipating work accidents (Q2) & Benefit & 10.6 \\
C5 & The ability to provide a consistent level of service (Q3) & Benefit & 10.5 \\
C6 & Ease of access to communicate (S1) & Benefit & 4.9 \\
C7 & Speed in providing responses or responses, both needs and complaints (S2) & Benefit & 9.0 \\
C8 & The ability to present information that is clear and easy to understand (S3) & Benefit & 5.1 \\
C9 & The ability to deliver goods according to time and place (R1) & Benefit & 7.1 \\
C10 & Ability in handling problems in the field (R2) & Benefit & 13.1 \\
\hline
\end{tabular}

Source: Results of research data processing (2019)

b. Make a match rating. Using a Likert rating scale, respondents were asked to rate alternative satisfaction levels (vendors) by putting a rating scale from 1 (Very Not Filled) to 5 (Very Filled) as the highest score for each criterion question. The results are shown in table 9, below.

Table 9. Match rating of each alternative for each criteria

\begin{tabular}{lcrrrrrrrrr}
\hline \multirow{2}{*}{ Alternative } & \multicolumn{10}{c}{ Criteria } \\
\cline { 2 - 11 } & C1 & C2 & C3 & C4 & C5 & C6 & C7 & C8 & C9 & C10 \\
\hline PT. Axx & 4 & 4 & 4 & 4 & 4 & 4 & 4 & 4 & 4 & 4 \\
PT. Nx & 4 & 3 & 4 & 4 & 3 & 4 & 4 & 4 & 3 & 3 \\
PT. Lxx & 3 & 3 & 3 & 3 & 3 & 3 & 2 & 2 & 2 & 2 \\
\hline Min & 3 & 3 & 3 & 3 & 3 & 3 & 2 & 2 & 2 & 2 \\
Max & 4 & 4 & 4 & 4 & 4 & 4 & 4 & 4 & 4 & 4 \\
\hline
\end{tabular}

Source: Results of research data processing (2019) 
c. Make a decision matrix $(\mathbf{X})$. From table 8 above, the next step is to make a decision matrix (Matrix X) based on Ci criteria that is adjusted to the type of attribute to obtain the following decision matrix $\mathrm{X}$ :

$$
\mathbf{X}=\left[\begin{array}{llllllllll}
4 & 4 & 4 & 4 & 4 & 4 & 4 & 4 & 4 & 4 \\
4 & 3 & 4 & 4 & 3 & 4 & 4 & 4 & 3 & 3 \\
3 & 3 & 3 & 3 & 3 & 3 & 2 & 2 & 2 & 2
\end{array}\right]
$$

d. Normalize the decision matrix (r). Normalize the decision matrix $\mathrm{X}$ by calculating the normalized performance rating value ( $r$ ) of the alternatives in the criterion $(\mathrm{Ci})$, with the following formula:

$\boldsymbol{r}_{i j}=\left\{\begin{array}{c}\frac{X_{i j}}{\operatorname{Max} X_{i j}}, \text { if } \mathrm{j} \text { is the benefit attribute } \\ \frac{\operatorname{Min} X_{i j}}{X_{i j}}, \quad \text { if } \mathrm{j} \text { is the cost attribute }\end{array}\right.$

Where: $\quad r_{i j} \quad=$ Normalized performance rating

$\operatorname{Max} X_{i j} \quad=$ Maximum value of each row and column

$\operatorname{Min} X_{i j} \quad=$ Minimum value of each row and column

$X_{i j} \quad=$ Rows and columns of the matrix

The Normalized matrix (r) results are listed in table 10 below.

Table 10. Normalized Matrix (r)

\begin{tabular}{lllllllllll}
\hline & C1 & C2 & C3 & C4 & C5 & C6 & C7 & C8 & C9 & C10 \\
\hline $\mathrm{R} 1=$ & 0.75 & 0.75 & 1.00 & 1.00 & 1.00 & 1.00 & 1.00 & 1.00 & 1.00 & 1.00 \\
$\mathrm{R} 2=$ & 0.75 & 1.00 & 1.00 & 1.00 & 0.75 & 1.00 & 1.00 & 1.00 & 0.75 & 0.75 \\
$\mathrm{R} 3=$ & 1.00 & 1.00 & 0.75 & 0.75 & 0.75 & 0.75 & 0.50 & 0.50 & 0.50 & 0.50 \\
\hline
\end{tabular}

e. Calculating Preference Value (Vi). Finally, the sum of the normalized matrix multiplication (r) with the weight value (wj) according to the preference formula :

$\boldsymbol{V}_{\boldsymbol{i}}=\sum_{j=1}^{n} w_{j} r_{i j}$

So that the greatest value will be chosen as the best alternative as a solution. The weight values for each criterion $(\mathrm{C} 1-\mathrm{C} 10)$ are:

$W=[0.054 ; 0.137 ; 0.207 ; 0.106 ; 0.105 ; 0.049 ; 0.090 ; 0.051 ; 0.071 ; 0.131]$

The details of the vendor value calculation process are as follows:

$$
\begin{aligned}
V_{1}= & (0.054 \times 0.75)+(0.137 \times 0.75)+(0.207 \times 1.00)+(0.106 \times 1.00)+(0.105 \times 1.00)+ \\
& (0.049 \times 1.00)+(0.090 \times 1.00)+(0.051 \times 1.00)+(0.071 \times 1.00)+(0.131 \times 1.00) \\
V_{\boldsymbol{I}=} & \mathbf{0 . 9 5 3 2 5} \\
V_{2}= & (0.054 \times 0.75)+(0.137 \times 1.00)+(0.207 \times 1.00)+(0.106 \times 1.00)+(0.105 \times 0.75)+ \\
& (0.049 \times 1.00)+(0.090 \times 1.00)+(0.0621 \times 1.00)+(0.071 \times 0.75)+(0.131 \times 0.75)
\end{aligned}
$$

$V_{2}=\mathbf{0 . 9 2 1 8 5}$ 


$$
\begin{aligned}
V_{3}= & (0.054 \times 1.00)+(0.137 \times 1.00)+(0.207 \times 0.75)+(0.106 \times 0.75)+(0.105 \times 0.75)+ \\
& (0.049 \times 0.75)+(0.090 \times 0.50)+(0.051 \times 0.50)+(0.071 \times 0.50)+(0.131 \times 0.50)
\end{aligned}
$$

$V_{\mathbf{3}}=\mathbf{0 . 7 1 5 8 1}$

Then the preference value is made in the form shown in table 11 below:

Table 11. Value of Preference Results

\begin{tabular}{rrrrrrrrrrrr}
\hline & C1 & C2 & C3 & C4 & C5 & C6 & C7 & C8 & C9 & C10 & Hasil \\
\hline V1 $=$ & 0.0405 & 0.10275 & 0.207 & 0.106 & 0.105 & 0.049 & 0.090 & 0.051 & 0.071 & 0.131 & 0.95325 \\
V2 $=$ & 0.0405 & 0.137 & 0.207 & 0.106 & 0.07875 & 0.049 & 0.090 & 0.0621 & 0.05325 & 0.09825 & 0.92185 \\
V3 $=$ & 0.054 & 0.137 & 0.15525 & 0.0795 & 0.07875 & 0.03675 & 0.045 & 0.02856 & 0.0355 & 0.0655 & 0.71581 \\
\hline
\end{tabular}

Source: Results of research data processing (2019)

Discussion of Results in the SAW Method. The preference value used by the project procurement team in selecting vendors, namely the ten criteria in the SAW method $(\mathrm{C} 1$ C10) has a weight value that is comparable to the AHP method (P1, P2, Q1, Q2, Q3, S1, S2, S2, S3, R1 and R2).

Overall, vendors of PT. Axx is rated as the best vendor with a priority weight value of 0.95325. Followed by PT. Nx occupies the second best vendor at 0.92185 and PT. Lxx as the third best vendor reaches 0.71581 . So that the best vendor for being recommended as the winner of a tender project by a company with the SAW method is PT. Axx because overall has the highest priority weight value compared to other alternatives. The comparative analysis is shown in table 12 and 13 below:

\begin{tabular}{|c|c|c|}
\hline Analysis Point & AHP method & The SAW method \\
\hline $\begin{array}{l}\text { Process Speed } \\
\text { Calculation }\end{array}$ & 9 Stages & $\begin{array}{l}4 \text { Stages } \\
\text { (Recommended) }\end{array}$ \\
\hline $\begin{array}{l}\text { Data Processing } \\
\text { Maturity }\end{array}$ & $\begin{array}{l}\text {-Pairwise Comparison } \\
\text {-S consistency test } \\
\text {-Normalizing Value } \\
\text { (Recommended) }\end{array}$ & Determine Value Normalization \\
\hline $\begin{array}{l}\text { Understanding the } \\
\text { process calculation }\end{array}$ & $\begin{array}{l}\text { The formula is many and difficult } \\
\text { understood }\end{array}$ & $\begin{array}{l}\text { The calculation formula is simple and few } \\
\text { (Recommended) }\end{array}$ \\
\hline $\begin{array}{l}\text { Effect of Number of } \\
\text { Criteria and Sub- } \\
\text { Criteria in the } \\
\text { Calculation Process }\end{array}$ & $\begin{array}{l}\text { The number of criteria and sub criteria is } \\
\text { very influential in the AHP method, } \\
\text { because the value of the number of criteria } \\
\text { and subcriteria }(\mathrm{n}) \text {, is used to calculate the } \\
\text { weight of criteria and is used to test the } \\
\text { consistency of the hierarchy. }\end{array}$ & $\begin{array}{l}\text { Not very influential, because in the } \\
\text { process of calculating the SAW method } \\
\text { there is no calculation to determine the } \\
\text { weighting of criteria and sub-criteria and } \\
\text { there is no consistency test stage. }\end{array}$ \\
\hline $\begin{array}{l}\text { Weighting Criteria } \\
\text { and Sub Criteria }\end{array}$ & $\begin{array}{l}\text { Determined in the calculation process, the } \\
\text { value is also based on comparison of } \\
\text { criterion values. }\end{array}$ & $\begin{array}{l}\text { It already exists, because the criteria and } \\
\text { sub-criteria have been determined by the } \\
\text { company / decision maker outside the } \\
\text { SAW Method calculation process. (this } \\
\text { research uses equal weight values) }\end{array}$ \\
\hline $\begin{array}{l}\text { Weighting Criteria } \\
\text { and Sub Criteria }\end{array}$ & $\begin{array}{l}\text { It is more suitable to be applied to } \\
\text { companies that have not determined the } \\
\text { weighting of the criteria and the scale of } \\
\text { their assessment and prioritizes the }\end{array}$ & $\begin{array}{l}\text { More suitable to be applied to a company } \\
\text { that has determined the weighting of its } \\
\text { criteria and the scale of its assessment and } \\
\text { prioritizes ease of implementation }\end{array}$ \\
\hline
\end{tabular}

Table 12. Comparison of Calculation Processes between Methods 
accuracy of the results calculation.

(Recommended)

(Recommended)

Source: Results of research data processing (2019)

Table 13. Comparison of Final Results between Methods

\begin{tabular}{|c|c|c|}
\hline Analysis Point & AHP method & The SAW method \\
\hline $\begin{array}{l}\text { Distance values from the } \\
\text { final score results }\end{array}$ & $\begin{array}{l}\text { The value per alternative (vendor) cannot be } \\
\text { measured, but if all alternative values are } \\
\text { accumulated, the value }=0 \text { to } 1\end{array}$ & $\begin{array}{l}\text { Distance value per alternative } \\
\text { (vendor) }=0 \text { to } 1\end{array}$ \\
\hline 1st Rank & $\mathrm{A} 1=0.592$ & $\mathrm{~A} 1=\mathbf{0 . 9 5 3 2 5}$ \\
\hline 2ndt Rank & $\mathrm{A} 2=0.274$ & $\mathrm{~A} 2=\mathbf{0 . 9 2 1 8 5}$ \\
\hline 3rd Rank & $\mathrm{A3}=\mathbf{0 . 1 3 4}$ & $\mathrm{A} 3=\mathbf{0 . 7 1 5 8 5}$ \\
\hline The highest score & 0.592 & 0.95325 \\
\hline The lowest Value & 0.134 & 0.71585 \\
\hline $\begin{array}{l}\text { Alternative ranking } \\
\text { based on final value }\end{array}$ & \multicolumn{2}{|c|}{ Both methods (AHP - SAW) produce the same ranking order } \\
\hline $\begin{array}{l}\text { Total Accumulated Final } \\
\text { Value }\end{array}$ & 1 & 2.59091 \\
\hline Vector value & $\begin{array}{l}\text { There are no similar vector values for different } \\
\text { criteria }\end{array}$ & $\begin{array}{l}\text { Possibility of similarity of vector } \\
\text { values for alternatives with } \\
\text { different criteria / sub-criteria } \\
\text { values }\end{array}$ \\
\hline Accuracy of Results & $\begin{array}{l}\text { The results obtained are more accurate when } \\
\text { compared with the calculation of the SAW } \\
\text { method }\end{array}$ & $\begin{array}{l}\text { The results obtained are less } \\
\text { accurate when compared to the } \\
\text { AHP method calculation }\end{array}$ \\
\hline
\end{tabular}

Source: Results of research data processing (2019)

\section{CONCLUSION AND SUGESTION}

\section{Conclusion:}

DSS can be developed based on the results of data processing using software, combined with expert sources of interest.

DSS Model AHP (Analytical Hierarchy Process) method, with the criteria used:

Quality (Q) consists of sub-criteria: Q-1 (20.7\%); Q-2 (10.6\%); Q-3 (10.5\%)

Reliability (R) consists of sub-criteria: R-2 (13.1\%); R-1 (7.1\%)

Price $(\mathrm{P})$ consists of sub criteria: P-2 (13.7\%); P-1 (5.4\%)

Services (S) consist of sub criteria: S-2 (9\%); S-3 (5.1\%); S-1 (4.9\%)

DSS Model SAW (Simple Additive Weighting) method with the criteria used, namely:

C3 (Quality-1) with a weight of $20.7 \%$

C2 (Price-2) with a weight of $13.7 \%$

C10 (Reliability-2) with a weight of $13.1 \%$

C4 (Quality-2) with a weight of $10.6 \%$

C5 (Quality-3) with a weight of $10.5 \%$

C7 (Service-2) with a weight of $9 \%$

C9 (Reliability-1) with a weight of $7.1 \%$

C1 (Price-2) with a weight of $5.4 \%$

C8 (Service-3) dengan bobot sebesar $5.1 \%$

C6(Service-1) dengan bobot sebesar $4.9 \%$ 
Between AHP and SAW methods show that rank 1 is occupied by the same alternative (vendor) but the difference is the acquisition of each value. The SAW method shows a higher amount than the AHP method.

The selection of vendor winners in the tender for the construction of MNC transmission stations in Denpasar has been determined with the main priority criteria being quality.

The comparison of SPK in the selection of tender winners using the AHP and SAW methods is summarized as follows:

\begin{tabular}{ll}
\hline \multicolumn{1}{c}{ Point of analysis } & \multicolumn{1}{c}{ Method comparison } \\
\hline Speed, understanding the calculation process & SAW is faster and easier \\
Data processing & AHP is more accurate \\
Number of criteria and sub-criteria & AHP is very influential \\
Weighting of criteria and sub-criteria & AHP is more complicated \\
Implementation in performance appraisal & AHP and SAW are equally important \\
Accuracy of results & AHP is more accurate \\
\hline
\end{tabular}

\section{Suggestion.}

Based on the results of the analysis of data that has been made for future development, as follows:

Expert Choice software can still be used to help decision makers choose vendors in order to facilitate the process of calculating the value given to vendors.

The decision making model is based on the criteria of price, quality, service and reliability on the AHP method.

Decision making model is based on the criteria of suitability and appropriateness of prices, the ability to provide discounts, the suitability of services provided with company specifications (KPI), the ability to anticipate work accidents, the ability to provide consistent service levels, ease of access communicate, speed in providing responses or responses, both needs and complaints, the ability to present clear and easy-to-understand information, the ability to deliver goods according to time and place, the ability to handle problems in the field on the SAW method.

Comparison of decision support systems in the two methods can be used, because each has advantages and disadvantages that are not sophisticated.

Using these two methods for combination and as a comparison will facilitate and increase the confidence of decision makers.

\section{REFERENCE}

Agnieszka Leśniak, Aleksandra Radziejowska. (2017). "Supporting bidding decision using multi-criteria analysis methods". Journal of Procedia Engineering 208, pp: 76-81 and online: www.sciencedirect.com

Dewi Nusraningrum, Joko Priyono. (2018). "Analysis of Cost Control, Time, and Quality on Construction Project". Journal of Management and Business, Vol. 17, No. 1.

Gede Surya Mahendra, Kadek Yota Ernanda Aryanto. (2019). "SPK Penentuan Lokasi ATM Menggunakan Metode AHP dan SAW". National Journal of Technology and Information Systems, Vol. 05 No. 01, pp: 049-056. 
Gray, Clifford F., Erik W. Larson. Dwi Prabantini's translation. (2007). Project Management: Managerial Process. Andi. Yogyakarta.

Janner Simarmata, Tonni Limbong, Mendarissan Aritonang, Sriadhi. (2018). "Sistem Pendukung Keputusan Pemilihan Guru Bidang Studi Komputer Menggunakan Metode Simple Additive Weighting (SAW)". CESS (Journal of Computer Engineering Systems and Science) Vol. 3 No. July 2, 2018 and online journal https://www.researchgate.net/publication/326766300.

Jeremy Y. L. Yap, Chiung Ching Ho, Choo-Yee Ting. (2018). "Analytical Hierarchy Process (AHP) for business site selection". Online journal https://www.researchgate.net/publication/316736276

Kitnas Dian Purwitasari, Feddy Setio Pribadi. (2015). "Implementasi Sistem Pendukung Keputusan Peminatan Peserta Didik SMA Menggunakan Metode AHP (Analytical Hierarchy Process) dan SAW (Simple Additive Weighting)". Teknik Elektro Journal Vol. 7 No. 2 Nationally Accredited (SINTA 2) SK: 36/E/KPT/2019

Maulita Lutfiani, Mohamad Syamsul Maarif dan Trioso Purnawarman. (2019). "Analisis Pendukung Keputusan Penilaian Prestasi Kerja Berdasarkan Sasaran kerja dan Perilaku Kerja Tenaga Kependidikan". MIX: Jurnal Ilmiah Manajemen, Volume 9, No. 1, Februari 2019

Merri Parida. (2017). "Sistem Pendukung Keputusan Penentuan Penilaian Karyawan Berprestasi Menggunakan Metode SAW dan AHP”. Prosiding ISSN: 2598 - 0246, E ISSN: $2598-0238$

Moh. Erkamim, Rendy Bagus Pratama, Wartono, Kusrini. (2018). "Penerapan Metode Simple Additive Weighting (SAW) Dalam Menentukan Posisi Duduk Peserta Didik". Jurnal Ilmiah Sinus (JIS) Vol: 16, No. 2, Juli 2018 and online journal https://www.researchgate.net/publication/327147916

Muhammad Donni Lesmana Siahaan, Elviwani, Asprina Br. Surbakti, Andre Hasudungan Lubis, Andysah Putera Utama Siahaan. (2017). "Implementation of Simple Additive Weighting Algorithm in Particular Instance". Jurnal IJSRST, Volume3, Issue 6, pp: 2395-6011 and online journal https://www.researchgate.net/publication/319271281

M Saputra, O S Sitompul, and P Sihombing. (2018)." Comparison AHP and SAW to promotion of head major department SMK Muhammadiyah 04 Medan". Journal of Physics: Conference Series, Conf. Series 1007 (2018) 012034

Ronda Deli Sianturi, Edward Robinson Siagian. (2017). "Simple Additive Weighting Method to Determine the Location of Fuel Station". IJSRST Journal, Volume 3, Issue 7, pp: 2395-6011

Seyit Ali Erdogan, Jonas Šaparauskas, Zenonas Turskis. (2016). "Decision Making in Construction Management: AHP and Expert Choice Approach". Journal of Procedia Engineering Vol.172, pp: 270-276 and online: www.sciencedirect.com

Sugiyono (2017). Metode Penelitian Kuantitatif, Kualitatif dan R\&D. 26th edition, October 2017. Alfabeta. Bandung

Sugiyono (2018). Metode Penelitian Manajemen. 6th edition, 2018. Alfabeta. Bandung

Winda Widyanty, Apollo Daito, Setyo Riyanto and Dewi Nusraningrum. (2020). "Gaining a competitive advantage through strategic human resource management in Indonesian construction industry". Management Science Letters 10 (2020) pp: 2021-2028 and online: www.GrowingScience.com/msl 